\title{
An Austrian in Hollywood: the representation of foreigners in the films of Billy Wilder
}

\author{
Delia Chiaro \\ University of Bologna, Italy \\ delia.chiaro@unibo.it
}

\section{Giuseppe De Bonis}

University of Bologna, Italy

giuseppe.debonis2@unibo.it

\begin{abstract}
This paper examines the work of Billy Wilder whose rich cinematic production frequently involves the collision of different languages as well as the clash of dissimilar cultures. As an Austrian living in the USA, the director had the privilege of gaining insight into his adopted culture from the point of view of an outsider - a bilingual "other" who made 25 films in almost 40 years of working in Hollywood. His films recurrently depict foreign characters at which Wilder pokes fun whether they are English, French, German, Italian, Russian or even the Americans of his adopted country. More precisely, the paper offers an overview of the multi-modal portrayals of diverse "foreigners," with examples taken from a small but significant sample of Wilder's films. The subtitling of dialogue in the secondary language for the target English-speaking audience and the specific translation solutions are not within the scope of this discussion, instead we focus on the comic collision of two languages and more importantly, on the way Wilder implements humour to highlight the absurdity of cultural difference. In other words, our main goal is to explore two or more languages in contrast when they become a humorous trope.
\end{abstract}

Keywords: humour, multilingualism, cultural stereotypes, representation of foreigners, multilingual humour

\section{Introduction}

Unlikely as this may sound, the Internet Movie Database reveals that since the birth of motion pictures, films and fictional TV series that include dialogues in more than one language by far outnumber products that are wholly monolingual (De Bonis 2015a, 2015b). As argued at length by Chiaro $(2015,2018)$, the presence of more than one language will typically occur in films about war, espionage and thrillers where multilingualism often highlights conflict. 
However, beyond conflict, the presence of more than one language on screen (and in real life) can also serve as a trigger for what we would like to define as "comic confusion" (Chiaro 2018). Two people lacking a common language can easily experience a series of misunderstandings that are, after all, a central underpinning of farce. Moreover, there is something inherently tragi-comic about the verbal disorder caused by the Babel effect when speakers of diverse languages attempt to interact.

For this paper, we have chosen to examine the work of Billy Wilder whose rich repertoire of films frequently involves the collision of different languages and, alongside this, the clash of dissimilar cultures too. Wilder himself was born in Sucha, Austria-Hungary (present-day Sucha Beskidzka, Poland), but fled Nazi Germany to become a screenwriter and then a director in Hollywood. As an Austrian living in the USA, Wilder had the privilege of gaining insight into his adopted culture from the point of view of an outsider - a bilingual "other" who made 25 films in almost 40 years of working in Hollywood. These films frequently involved foreign characters at which Wilder pokes (caustic) fun whether they are English, French, German, Italian, Russian or even the Americans of his adopted home themselves. In fact, Wilder was especially good at mocking Americans by setting them up against a foreign "other" and highlighting that no culture is superior to another and that one culture's rituals, habits and values, while being different from those of another culture, are no better or worse but just different.

In this paper, we focus on four films in which Wilder not only marks foreignness - as he does in films such as Irma La Douce (1963) that is set in Paris, yet in which all the French characters speak English - but comedies that include languages other than English. The subtitling of film dialogue uttered in these languages and the specific translation solutions are not within the scope of this discussion; instead we focus on the comic collision of different languages, and more importantly, on the way Wilder implements humour to highlight the absurdity of cultural difference. In other words, in an attempt to look beyond well-trodden arguments regarding dubbing and subtitling, we set out to explore translation itself, in its widest sense. We examine what happens when dialogue is reflected in the presence of two characters attempting to communicate with each other, each in their own language, each attempting to translate for the other and thus transforming the act of cross-cultural communication itself into a humorous trope.

\section{Cross-language humour}

Misunderstanding is a frequent trope adopted in comedy between speakers of two different languages and Wilder's films provide us with many first-rate examples. In Avanti! (1972), a comedy of errors set on the Italian island of Ischia, when a group of locals attempt to extort money from all-American executive Wendell Armbruster (Jack Lemmon), he threatens to sue them. Unfortunately for him, the crooks misunderstand the word "sue" (as in "He will sue you!") uttered by an Italian, for the word "screw" instead (i.e. "He will screw you!") - a simple enough misunderstanding, yet at the same time appalling enough to cause offence and for comic mayhem to follow. Similarly, in One, Two, Three, (1961) a farce set in Cold-war Berlin, another American executive, C.R. "Mac" MacNamara (James Cagney) is ostensibly shocked when a jeweller shouts the word "Schmuck" at him. Mac does not know that Schmuck is the German word for "jewellery" and is therefore shocked when hearing what in US English is an insult. This is an instance of what Delabastita $(2002,2005,2010)$ and Chiaro $(2007,2010)$ label a "target language monolingual pun." Only those familiar with the US meaning of "schmuck," meaning idiot, can get the joke. In another scene of the same film, a doctor tells a 
young American woman who is feeling unwell that she is pregnant, but as he cannot remember the English word for the condition, so he uses the German word "schwanger:"

\section{Example 1}

German doctor: Schwanger. You know... Such a Dummkopf I am! Schwanger, schwanger, schwanger...

It takes a while for the English-speaking characters to understand that the doctor is trying to tell them that the young woman in question is pregnant and for the comic farce to complicate further, "That is the word! Pregnant" says the doctor triumphantly. "Auf Wiedersehen! Schwanger is pregnant, pregnant is schwanger!" Wilder's comedies relish in such bilingual fun, yet we would like to take the discussion up a notch and consider how cross-language humour is principally based on transcultural differences which are, of course, conveyed by language, but not only. The German doctor leaves the house happy that he has remembered the English term "pregnant", yet the fact that Wilder has him walk away humming the tune of Wagner's Ride of the Valkyries - remember that we are in Berlin in 1961 - speaks louder than words (see De Bonis 2014a, 2015c). This musical addition feeds into the commonplace of "bad Germans" by alluding to Hitler's favourite composer and the Third Reich's fascination with him.

What follows is an overview of the multi-modal portrayals of diverse "foreigners," namely Germans, Russians, French, and Italians, with examples taken from a small but significant sample of Wilder's films.

\section{Bad Germans}

One, Two, Three is a film set in West Berlin during the summer of 1961 just a few months before the construction of the notorious wall that would separate the city for almost 30 years. The film opens with views of Berlin and Mac's voiceover (James Cagney) that sets the tone for Wilder's send-up on the Cold War:

\section{Example 2}

Mac: [voiceover] On Sunday, August $13^{\text {th }}$, 1961, the eyes of America were on the nation's capital, where Roger Maris was hitting home runs 44 and 45 against the Senators. On that same day, without any warning, the East German Communists sealed off the border between East and West Berlin. I only mention this to show the kind of people we're dealing with - real shifty! Some of the East German police were rude and suspicious. Others were suspicious and rude.

Mac is criticising communism, but at the same time, Wilder is poking fun at the USA and the shallowness of its people exemplified through the importance given to baseball. From the very start, the audience is aware of US anti-communist feeling, as with Wilder's tongue firmly in his cheek we learn that East Germans are shifty, rude, and suspicious. To add to the irony, we learn that Mac is lead executive at the Coca Cola division, a soft drink that denotes the US way of life and, of course, capitalism.

The plot thickens when, in order to make a good impression on his boss from Atlanta, Mac accepts to host his seventeen-year-old daughter, Scarlett Hazeltine (Pamela Tiffin), at his home in Berlin. The task immediately turns out to be much harder than he had initially thought as the girl is literally a whirlwind - she defines herself as a "hot-blooded woman" - not only is Scarlett impulsive and naïve, but she also seems more interested in dating men than sightseeing. To Mac's dismay, Scarlet secretly marries Otto Piffl (played by Horst Buchholz), 
an East German student with overt communist tendencies. The cross-language homophonic pun with Otto's surname, "Pifl," and the English word "piffle" is clearly intended. "Piffle" means nonsense and the name highlights that the collectivist ideals Otto continually expresses are to be considered pure and utter drivel. However, firmly determined not to compromise his career, Mac resorts to a trick and has Otto arrested by the East German Police with the charge of being "ein amerikanischer Spion."

The scene in which the police interrogate Otto, represents an interesting example of multilingual humour in which stereotypical national identities play a prominent role. The scene plays on the stereotype of "Bad Germans" and the widespread perception of Germans wearing military uniforms and typically being harsh, violent with a tendency to shout at people (Davies 1990). The dialogue between Otto and the East German police officers proceeds in Example 3 as follows:

\section{Example 3}

Character

Otto:

First German officer:

Otto:

First German officer:

Otto:

Second German officer:

Otto:

Second German officer:

Otto:

\begin{abstract}
First German officer:
Otto:
\end{abstract}

First German officer:

Otto (shouting it out):

\section{Dialogue}

Nein, nein. Genug, aufhören! Hör' auf! Ich will schlafen. Ich will schlafen. Lass mich nur schlafen!

Sind Sie ein amerikanischer Spion?

Nein.

Für wem arbeiten Sie? CIA?

Nein. Ich will schlafen.

Sind Sie ein amerikanischer Spion?

Nein.

Sind Sie ein Geheimagent von Allen Dulles?

Nein, nein. Lass mich schlafen. Ich will nur schlafen. Aufhören! Aufhören! Ich halte das nicht mehr aus. Ich gestehe. Ich gestehe! Ich gestehe!

Sie gestehen was?

Alles.

Sind Sie ein amerikanischer Spion?

$J a$, ich bin ein amerikanischer Spion. Ja, ich arbeite für die CIA. $J a$, ich bin von Wall Street bezahlt. $J a$, ich bin ein Geheimagent von Allen Dulles. Ja, ja, ja!

\section{English Gloss}

No. Enough, stop! Stop it! I want to sleep. I want to sleep. Just let me sleep!

Are you an American spy?

No.

Who do you work for? CIA?

No. I want to sleep.

Are you an American spy?

No.

Are you a secret agent of Allen Dulles?

No. Let me sleep. I just want to sleep. Stop it! Stop it! I can't stand it anymore. I confess. I confess! I confess!

What do you confess?

Everything.

Are you an American spy?

Yes, I am an American spy. Yes, I work for the CIA. Yes, I am paid by Wall Street. Yes, I am a secret agent of Allen Dulles. Yes, yes, yes!

[A third German officer meticulously types every single word uttered by Otto. His typewriting efficiently follows the frenetic pace of Otto's confession. The officer hands the sheet of paper to his colleague.]

First German officer: Unterschreiben. Sign it.

[Otto signs the confession.]

For monolingual English-speaking audiences, the situation soon turns into a grotesque farce as a number of different elements combine to create the overall humorous effect. Throughout his interrogation, Otto is "tortured" by being obliged to listen to the well-known pop song by Brian Hyland Itsy Bitsy Teenie Weenie Yellow Polka Dot Bikini, played non-stop at maximum 
volume and with different variations of pitch. Otto is anti-capitalist and covers his head and ears with his hands begging for the torture to stop. Furthermore, the German officers unceasingly yell at Otto and repeatedly ask him the same question, "Sind Sie ein amerikanischer Spion?" The violence of their behaviour consisting of a combination of attempts at brainwashing and mental torture is counterbalanced by the happy-go-lucky rhythm of the American pop song. The humorous effect lies in the evident contrast between a symbol of the American way of life through the silly song and Otto's fierce anti-American and anticapitalistic feelings. Finally, the interrogation ends surreally, as tired and exhausted Otto, confesses to being what he actually is not, namely an American spy. One, Two, Three is built on the opposition of cultural identities: Americans vs. Russians, West Germans vs. East Germans, capitalists vs. communists (see De Bonis 2014a).

The dialogue in the "torture scene" is entirely in German with no English subtitles. This is a case of so-called "contextual translation" (Baldo 2009, De Bonis 2014b) in which the audiovisual codes, combined with the elements described above, help and sustain viewers' understanding of what they see and hear on screen. Multilingual humour seems to operate beyond any language barrier as the scene ends up speaking for itself. The plot has led its viewers to this point and no translation appears necessary.

Wilder also mocks the Germans through a number of non-verbal features. Each time Mac walks through the main offices of his company, the German staff stand to attention and each time he has to tell them to sit down with a loud and angry, "Sitzen machen!" Repeated throughout the film several times it becomes a comic trope, together with the behaviour of Mac's first assistant, Schlemmer (Hanns Lothar) who consistently stands up straight and clicks his heels when carrying out an order. Furthermore, Mac's wife addresses her bossy, disagreeable husband with Mein Führer. All this reminds present-day audiences of the notorious Fawlty Towers sketch about "The Germans" with the difference that Wilder makes no pretence that he is accidentally referencing the Nazis and the war. Wilder's references are deliberate as reflected in Schlemmer who relishes in receiving orders, especially when they are given with loud urgency, as they remind him of the "good old days:"

\section{Example 4}

\section{Character Dialogue}

Mac: $\quad$ Schlemmer, I want all those people out there to drop everything and stand by for orders! General alarm, complete mobilization!

Schlemmer: Ah, like the good old days, yes, sir!

Ironically, Mac challenges Schlemmer regarding his nostalgia for the past and by doing so, through Schlemmer's droll response, Wilder reveals the shame and the element of taboo that Germans still attach to Nazism:

\section{Example 5}

$\begin{array}{ll}\text { Character } & \text { Dialogue } \\ \text { Mac: } & \text { Of course, you were anti-Nazi and you never liked Adolf. } \\ \text { Schlemmer: } & \text { Adolf who? }\end{array}$




\title{
4. Better dead than red? The Russians
}

A subplot of One, Two, Three consists of Mac's attempts to sell Coca Cola across the entire Soviet Union, by striking a deal with three Russian bureaucrats. Interaction between Mac and the trio mostly consists of tirades of one-upmanship regarding the various accomplishments of the two great powers. For example, the cuckoo clock in Mac's office contains a figurine of Uncle Sam instead of a cuckoo so that each time the clock strikes Uncle Sam appears to the tune of Yankee Doodle Dandy.

\section{Example 6}

\section{Character Dialogue}

Peripetchikoff: While they are putting Uncle Sam in cuckoo clock, we will put Soviet cosmonaut on moon.

Mac: Okay, so you guys may be the first to shoot a man to the moon, but if he wants a Coke on the way, you'll have to come to us.

This display of one-upmanship consistently has the Russians bragging about their technological and/or cultural superiority over the Americans, and Mac retorting with the economic accomplishments and success of US products - considering the name of film's main character, Mac, it is almost as if Wilder had foreseen the present-day Macdonalization of the world. Furthermore, the Uncle Sam replica in the clock is a clear intertextual reference to Cagney himself who appeared in the eponymous 1942 musical in the part of George M. Cohen aka Yankee Doodle, so Wilder is truly highlighting Americana albeit in comic mode. However, to the three Russians, the Americans remain a bunch of cultural philistines:

\section{Example 7}

\author{
Character Dialogue \\ Peripetchikoff: Instead of dollars, you would accept three-week tour of Bolshoi Ballet? \\ Mac: $\quad$ Please, no culture, just cash. \\ Mishkin: The Ugly American!
}

These examples of Cold War banter display the gullibility (and possible brainwashing) of both cultures. At times the Russians are depicted as stupid, although at the same time endearing:

\section{Example 8}

Peripetchikoff: We have emergency meeting with Swiss Trade Delegation. They send us twenty carloads of cheese. Totally unacceptable... full of holes.

And at others, they display great astuteness:

\section{Example 9}

\author{
Character Dialogue \\ Peripetchikoff: Here, take one of these [offering Mac a cigar]. \\ Mac: $\quad$ Thanks. Hm, "Made in Havana." \\ Peripetchikoff: We have trade agreement with Cuba. They send us cigars, we send them rockets. \\ Mac: Good thinking. [Begins to cough and splutter on the cigar.] You know \\ something? You guys got cheated. This is a pretty crummy cigar. \\ Peripetchikoff: Do not worry. We send them pretty crummy rockets.
}


As the Russians desperately try to convince Mac to sell them the formula for Coca Cola, Wilder pulls out several comic Russian stereotypes. Mac refers to Russia's failed attempts to reproduce the famous soft drink, he jokes about the USSR's attitude towards its so-called "satellite countries," about spies and secret agents as well as Soviet citizens' loyalty to the state with the trio's string of "No comment[s]" in response to a series of accusations.

\section{Example 10}

$\begin{array}{ll}\text { Character } & \text { Dialogue } \\ \text { Peripetchikoff: } & \text { No formula, NO DEAL! } \\ \text { Mac: } & \text { OK, NO DEAL! } \\ \text { Borodenko: } & \text { We do not need you! If we want Coca cola, we invent it ourselves! } \\ \text { Mac: } & \text { Oh, yeah? In 1956, you flew a bottle of Coke to a secret laboratory in Sverdlovsk. } \\ \text { Aishkin: } & \text { A dozen of your top chemists went nuts trying to analyse the ingredients. Right? } \\ \text { Mac: } & \text { And in 1958, you planted two undercover agents in Atlanta to steal the formula. } \\ & \text { And what happened? They both defected! And now they're successful } \\ \text { beripetchikoff: } & \text { No comment! } \\ \text { Mac: } & \text { Last year you put out a cockamamie imitation "Kremlin-kola!" You tried it out in } \\ & \text { the satellite countries, but even the Albanians wouldn't drink it. They used it for } \\ \text { Mishkin: } & \text { SHEEP DIP! RIGHT? } \\ & \text { No comment! }\end{array}$

Most importantly, through the Russian trio, Wilder also mocks Mac and the nation that he represents. Mac's wife, Phyllis (played by Arlene Frances), wants to return to the States, but Mac disagrees:

\section{Example 11}

\section{Character Dialogue}

Peripetchikoff: Why can't you get yourself a nice permanent job with the home office in Atlanta? Mac: Atlanta? You can't be serious! That's Siberia with mint juleps!

Otto Pifl also ridicules the American way of life with comments like "Capitalism is like a dead herring in the moonlight. It shines, but it stinks." Yet his comments about collectivism are also unwittingly scathing towards communism itself, such as when he tells his new bride that in Moscow they will have all their meals in bed. Audiences soon learn that the couple will eat and drink in bed, not because they are newlyweds but owing to the lack of a table in the "magnificent apartment" they have been assigned "just a short walk from the bathroom."

According to Wilder, no one culture has found the right life-style formula. When Otto declares that he will not have his son grow up to be a capitalist, Scarlett astutely replies that "When he is 18 , he can make his mind up whether he wants to be a capitalist or a rich communist." 


\section{The French and l'amour}

From Germans and Russians we now move on to discuss the way in which Wilder represents France and the French. We will examine two films, Sabrina (1954) and Love in the Afternoon (1957), both starring Audrey Hepburn in the leading role.

The eponymous character of the first film is Sabrina Fairchild, daughter of the chauffeur of the Larrabees, a family of billionaires from Long Island. All her life Sabrina has been in love with David, the Larrabees' second son, but much to her dismay, David (played by William Holden), who is an idle playboy and incorrigible bon viveur, has never noticed her. After trying to commit suicide, Sabrina finally decides to leave for Paris with the intention of getting over him and spends two long years in France attending a prestigious culinary school, but this does not help her to forget David.

The first scene set in Paris, opens with the close-up of a circular window looking out onto the Eiffel Tower. This "postcarding" method (Wahl 2005, 2008) continues with the camera closing in on a stereotypical moustachioed chef dressed in a crisp white uniform complete with toque, necktie, double-breasted jacket and apron. We are at a cookery school and the chef (played by German actor Marcel Hillarie ${ }^{1}$ ) addresses his students with a broad French accent:

\section{Example 12}

The chef: Bonjour, mesdames et messieurs! Yesterday we have learned the correct way how to boil water. Today we will learn the correct way how to crack an egg. Voilà an egg! Now, an egg is not a stone; it is not made of wood. It is a living thing with a heart. So when we crack it, we must not torment it. We must be merciful and eggsecute it quickly, like with the guillotine. Zac! It is done with one hand! Kindly watch your wrist! Voilà! One, two, three, crack! You see? It is all in the wrist! And now, everybody, take an egg! One, two, tree, crack!

Wilder slips in a cross-language pun with "egg/execute" and a good dose of visual ridicule of the chef walking around the room to inspect his trainees' results. Sabrina's first attempt at cracking the egg is unsuccessful. She reluctantly shows the chef the broken egg crushed in the palm of her hand. The chef promptly comments: "The wrist? Huh? Like a whip. You watch! One, two, three, crack!" However, he fails to crack the egg correctly and ends up with the egg stuck to his hand, exactly as had happened to Sabrina. This representation of the French chef is highly stereotypical. He is a well-built man with a perfectly groomed moustache, all dressed up for the role, talking about la cuisine française with an assertive tone of superiority. Alongside his attitude, the comic effect is increased by his use of language. Apart from his exaggerated French accent (and his use of the word "how," for example), it is the content of his explanation (the what) that puts a smile on viewers' faces. "An egg is a living thing with a heart. And we must not torment it", he says, to immediately contradict himself by claiming "We must be merciful and [egg] execute it quickly, like with the guillotine. Zac!" The mismatch between mercy and the guillotine is so evident that one might wonder how a violent action such as cutting someone's head off could be ever merciful. The answer is simple if we accept the French way of doing it. It is no coincidence that such a stereotypical representation of France is reinforced with one of the nation's biggest national emblems, the guillotine, symbol of the 1789 Revolution that has led to the birth of contemporary France.

${ }^{1}$ On Marcel Hillaire IMDb reports: "Marcel was another scene-stealing character actor who came to the fore during the early years of television. He built a 40-year long career in Hollywood playing the archetypal French gendarme, maître or small time crook. [...] Marcel excelled in comical portrayals of stereotypical characters." (https://www.imdb.com/name/nm0384787/bio?ref_nm_ov_bio_sm, last accessed: October 15, 2018). On this point, see our discussion infra. 
Sabrina's culinary misadventures persist throughout her culinary education. So much so that some days later, during the soufflé lesson, she has to face another catastrophe:

\section{Example 13}

Character

The chef:

Sabrina:

Baron St. Fontanel:

Sabrina:

Baron St. Fontanel:

\section{Dialogue}

[inspecting the students' soufflés] Too low. Too pale. Too heavy. Too low. Too *high*, you are exaggerating. Fair. So-so. Sloppy [addressing Baron St. Fontanel] Mm. Supèrbe. My dear Baron, you have not lost your touch. [He looks at Sabrina's soufflé] Much too low!

[looking at her soufflé] I don't know what happened.

I will tell you what happened; you forgot to turn on the oven.

$\mathrm{Oh}$ !

A woman happily in love, she burns the soufflé. A woman unhappily in love, she forgets to turn on the oven.

And here we have the other great stereotype regarding the French as being experts regarding the art of romance as the Baron links a woman's love life to her ability to make a soufflé rise correctly.

Apart from this chef, the way in which Wilder typecasts the French in these two films is much more subtle than the way he teases other cultures in other films. Both Sabrina and Love in the Afternoon play on the trope that sees the French as sophisticated lovers and attacks Americans, as in all the other films examined, as being obsessed with money and financial gain.

If Sabrina seems to struggle with French cuisine, nonetheless, her stay in Paris proves to be helpful on a more personal level. Upon her return to the USA, she has completely changed from a naïve and clumsy young girl into a sophisticated and elegant young woman. In France, Sabrina has learnt how to enjoy life, as she repeats on several occasions. In a letter to her father, she explains: "I have learned how to live, how to be in the world and of the world, and not just to stand aside and watch. And I will never, never again run away from life. Or from love, either." The well-known tune La vie en rose sung by Edith Piaf becomes Sabrina's personal anthem as an invitation to seeing the world through rose-coloured glasses, so much so that as she arrives home, she fiercely sings Piaf's song out loud. While waiting for her father to pick her up at the train station, Sabrina bumps into David who does not recognise her at first. She immediately takes the chance to play the part of the femme fatale: her masquerade seems to be quite effective, as David feels an instant attraction for this unknown woman and immediately starts courting her.

Since David is officially engaged to Elizabeth Tyson, the daughter of a sugar baron, whose company his elder brother Linus (Humphrey Bogart) wants to merge with that of the Larrabees, Linus deliberately decides to step in between David and Sabrina with the calculating intention of saving the profitable deal between the two companies. Linus has a precise plan: he wants to woo Sabrina and then send her back to Paris for good. The two start going out together and Linus finds himself more caught up with Sabrina than he even remotely imagined. One night, while having dinner at a fashionable restaurant, Sabrina and Linus dance together to the strains of La vie en rose in the background. The dialogue between them proceeds as follows: 


\section{Example 14}

$\begin{array}{ll}\text { Character } & \text { Dialogue } \\ \text { Linus: } & \text { How do you say in French my sister has a yellow pencil? } \\ \text { Sabrina: } & \text { Ma soeur a un crayon jaune. } \\ \text { Linus: } & \text { How do you say my brother has a lovely girl? } \\ \text { Sabrina: } & \text { Mon frère a une gentille petite amie. } \\ \text { Linus: } & \text { And how do you say I wish I were my brother? }\end{array}$

In the film, French is not only the language of female empowerment, but also becomes the language of love. The scene exploits the romantic connotation of French as la langue de l'amour. The humour here lies in the fact that Linus resorts to this elementary French language lesson to let Sabrina know that he has feelings for her. Multilingualism functions as a strong vehicle for increasing the subtle irony of the situation. If from Linus' perspective, this is just a fake declaration of love, a way of deceiving poor Sabrina, viewers know that it is actually a true confession of love. Audiences are well aware of Linus' feelings for her, and understand he is falling in love with her long before he does. This sophisticated game of anticipation is what makes the audience smile. This apparently harmless conversation is the first clue that things will not go according to Linus' plans and that he will fall in love with Sabrina and she with him. Comedy combines with romance and concludes with a happy ending.

\section{Example 15}

\section{Character Sabrina:}

\section{Dialogue}

Oh, but Paris isn't for changing planes, it's... it's for changing your outlook, for... for throwing open the windows and letting in... letting in la vie en rose.

Linus:

[sadly] Paris is for lovers. Maybe that's why I stayed only thirty-five minutes.

The un-romantic American shying away from love turns up once more in Love in the Afternoon. The film opens with a number of views of well-known Parisian landmarks and with the voiceover of private eye Claude Chavasse (Maurice Chevalier) waxing lyrically about the "City of Love:"

\section{Example 16}

Claude Chavasse: [voiceover] This is the city - Paris, France. It is just like any other big city London, New York, Tokyo - except for two little things. In Paris, people eat better. And in Paris, people make love - well, perhaps not better, but certainly more often. They do it any time, any place. On the left bank, on the right bank, and in between! They do it by day, and they do it by night. The butcher, the baker, and the friendly undertaker. They do it in motion, they do it sitting absolutely still. Poodles do it. Tourists do it. Generals do it. Once in a while even existentialists do it. There is young love, and old love. Married love, and innocent love. That is where I come in. My name is Claude Chavasse. I am what you would call a private eye.

Davies has published extensively about the notion of French lovers and how they are popular material for jokes and farces (Davis 1990, 1998, 2002) and that the common imaginary sees the French involved is perpetual sexual activity. This opening voiceover gives strength to this idea as the camera homes in on numerous couples publicly kissing and embracing. In Love in the Afternoon, Hepburn plays the part of Ariane Chavasse, the detective's daughter, who, like Sabrina is a naïve girl who knows nothing about the real world, let alone men. Her only passion is playing the cello and secretly reading the files of her father's old cases from his archive. One day, she overhears the conversation between her father and Monsieur X (John 
McGiver), a client who has just received proof of his wife's infidelity. Monsieur X announces that he intends to shoot her wife's lover the same night. The man is the notorious American playboy Frank Flannagan (Gary Cooper). Ariane calls the police to alert them about a jealous husband who has threatened to kill his unfaithful wife and her lover at the Ritz Hotel but the reaction of the police officer on the other end of the phone is not only calm and collected, but practically normalizes adultery:

\title{
Example 17
}

\section{Character Ariane: Commissaire de Police:}

\author{
Dialogue \\ You've got to stop him! You must send somebody up there immediately! \\ Madame, there are 7,000 hotels in Paris, 220,000 hotel rooms... and on a night \\ like this, I'd say in about... 40,000 of those rooms, a similar situation... Now \\ really, Madame, if we were to assign a policeman... to every one of these \\ situations... No, Madame, it just staggers the imagination. It would take more than \\ the entire Paris police force. It would take the fire department, the sanitation \\ department... and possibly the Boy Scouts. Certainly, we don't want young boys \\ in short pants... involved in situations like this.
}

Determined to avoid a tragedy, Ariane breaks into Flannagan's suite at the Hotel Ritz to warn the man and arrives in time to replace Monsieur X's wife before the latter bursts into the room. However, this mysterious girl, who refuses to provide him with any personal details about herself, even her name, intrigues Flannagan. The American libertine decides then to call Ariane "thin girl" and invites her to see him again the following day, being his last in Paris. Ariane reluctantly accepts his invitation and they spend the entire afternoon together until the man's departure from the hotel. Ariane accompanies him to the taxicab waiting for him at the entrance: where four porters from the Ritz say goodbye to him in French: "Merci, Monsieur Flannagan! Bon voyage!" as he hands each of them a tip. When he is about to say goodbye to Ariane, Flannagan immediately hold his hand back to hide the banknotes. Before he can utter a single word, Arianne anticipates him by saying:

\section{Example 18}

\section{Character \\ Ariane: \\ Flannagan:}

Ariane:

Flannagan:

Ariane:

Flannagan:

Ariane:

\author{
Dialogue \\ Merci, Monsieur Flannagan! Bon voyage! \\ Agatha? Angela? Well, whatever your name is, it was so sweet. I wish we had \\ more than just this one evening! \\ You don't really. Why drag it out? Scenes, tears... Everything is so morbid! This \\ way it was just perfect. \\ You know I come to Paris every year. Maybe we will see each other again. \\ Maybe. If someone tries to shoot you again. \\ I wish Cartier was open to buy you something very lavish. \\ I don't want anything from you. Yes, I do too. May I? [takes a flower from his \\ jacket breast pocket and smells it passionately.]
}

Though the story is entirely set in Paris, the characters all speak English throughout the film. Not only does English replace French, thus becoming the film's dominant language (cfr. De Bonis 2014b), but it is also used as a vehicular language between French characters and the American main character. The presence of French is limited to a few easily comprehensible words (on the homogenising convention see Sternberg, 1981, O'Sullivan 2011, De Bonis $2014 b, 2015 a)$. This scene is one of the few exceptions. The use of French in the dialogue has a double effect. On the one hand, it functions as a means to highlight Ariane's overplayed 
detachment and indifference. The implicit sub-text is actually quite the opposite: "I don't want you to leave. I don't want you to leave me." Ariane thus starts to play the part of the French femme fatale. On the other hand, strictly connected to the former, the surreal situation makes viewers smile, as they know exactly what is happening, even before Ariane herself knows. They know it is all a façade on her part, a masquerade.

The scene marks a turning point in the plot. After a year, Flannagan returns to Paris. The two start seeing each other again. Ariane, completely in love with him, plays the part of a worldly socialite with a list of lovers as long as his - Flannagan himself is number 20 on her list. Initially amused, Flannagan gradually finds himself tormented by the possible comparisons. By the end of the film, Ariane, the femme fatale is able to make an idle playboy like Flannagan fall in love for the very first time. However, just before they become an item, Flannagan provides an amusing piece of cross-cultural wordplay:

\section{Example 19}

Flannagan: You French girls have the right idea, bonjour and adieu and in between a little amour.

The film concludes with l'amour, the same topic with which the film has started in its opening scene, with Chavasse once more providing the voiceover:

\section{Example 20}

Claude Chavasse: On Monday, August 24th of this year, the case of Frank Flannagan and Ariane Chavasse came up before the superior judge in Cannes. They are now married, serving a life sentence in New York, state of New York, USA.

As the other films examined so far, this movie focuses on how strange certain American habits appear to the others too. Describing Flannagan to a friend Ariane says:

\section{Example 21}

\section{Character $\quad \underline{\text { Dialogue }}$}

Ariane: They're very odd people, you know. When they're young, they have their teeth straightened, their tonsils taken out and gallons of vitamins pumped into them. Something happens to their insides! They become immunized, mechanized, airconditioned and hydromatic. I'm not even sure whether he has a heart.

Michel: What is he? A creature from outer space?

Ariane: $\quad$ No. He's an American.

However, what the Americans in all these films have in common, is surely their obsession with money. Mac, the Larrabees and Flannagan put money before love, as does Wendell Armbruster in Avanti! Luckily, Wilder saves them from their financial fate at the last minute, and each time it is a romantic relationship that saves them.

\section{Italy - not a country, an emotion}

Avanti! (1972) is set on the Italian island of Ischia where American executive Wendell Armbruster (Jack Lemmon) has travelled to bury his father. After a sequence of twists and turns, Armbruster falls in love with the daughter of his late father's longstanding lover, Pamela Piggott (Juliette Mills), a sale's assistant from London who is on Ischia to bury her mother. An American and a Brit divided by the same language surrounded by Italians provide all the necessary ingredients for a lingua-cultural romp. 
The opening scene of Avanti! sets the tone for our discussion of the comic misunderstandings that can occur when one or more languages are at play. As the Alitalia plane is about to take off from the Baltimore tarmac, an Italian flight assistant instructs passengers to fasten their seatbelts and put out their cigarettes. However, when she translates the instructions into English she actually asks passengers to "Please fasten your cigarettes and extinguish your seatbelts." This confused and confusing imperative is a reflection of the whole film. Avanti! as all Wilder's comedies, pivots on farce, if it is not the case of switching words so that they are in the wrong place, it is often the case of the wrong person or even the wrong corpse being where it should not be.

In fact, in terms of language, Avanti! contains several instances of misunderstanding based on false cognates. Armbruster and Piggott are staying in the same hotel in Ischia when he burns his hands with hot tap water and she explains why:

\section{Example 22}

\section{Character Dialogue}

Armbruster: Water says "cold" and I burned my hands!

Pigott: $\quad$ So did I! Then I looked it up in my phrase book. C stands for calda but that doesn't mean "cold" it means "hot". Freddo means "cold."

Although by no means a bilingual pun, what we actually have is another instance of translation-based monolingual target-language wordplay (Chiaro 2017: 426). The joke is monolingually language based because calda is similar to the English word "cold," yet it means the opposite. It is "target based" because there is no ambiguity in meaning in the source Italian word. In order to "get" the joke, you have to know English. However, Pamela Piggott is enamoured with the Italian language:

\section{Example 23}

Piggot: In Italian, everything sounds as if it's from an opera! Non c'è sapone nel bagno. Do you know what that means? "There's no soap in the bathroom" $[\ldots]$ and when you're in a ristorante, that's a "restaurant," do you know there are 16 different kinds of pasta? Spaghetti, spaghettini, maccheroni, cannelloni, rigatoni, tortellini, fettuccine, manicotti, gnocchi, linguini, ravioli...

This exemplifies the way in which language is frequently reified. In the common imaginary, Italian is considered a so-called "musical" language yet there is nothing musical about soap and bathrooms, but according to Miss Piggott in Italian the phrase takes on a romantic meaning. She also relishes in the way the names of the various types of pasta roll off her tongue, but more than this she romanticises on the term avanti.

\section{Example 24}

Piggot: ... and in a hotel, before a maid enters your room, she asks permesso and if you want her to come in, you say avanti - "forward."

The film is farcical and there is much knocking on doors and the word avanti is uttered many times throughout, thereby creating a leitmotiv, but also recalling how "forward" the deceased couple were with their elicit love affair. We learn at the end of the film that the same affair will be emulated by their offspring who we leave looking forward to a lifetime of a somewhat unconventional relationship. 
In this film, every imaginable Italian commonplace appears as a humorous commonplace, food, music, and above all la dolce vita. But as in all the movies discussed so far, Wilder is especially biting when he mocks Americans, and as in all the films, the main male character is rich and seems to think money can buy anything. One thing Armbruster cannot buy, for example, is time. In the Italy of the early seventies (and in many places still today) shops and offices close for a lengthy lunchtime break and siesta. For Armbruster time is money and he needs to get his father's corpse back to Baltimore in a couple of days, but he is held up for numerous reasons, amongst which we find long Italian-style lunch breaks. Carlo Carlucci (Clive Revill), the hotel manager, explains to him:

\section{Example 25}

\section{Character} Carlo Carlucci: Armbruster: Carlo Carlucci:

\section{Armbruster: Carlo Carlucci:}

\author{
Dialogue \\ In Italy, the lunch hour is from one to four. \\ *Three hours* for lunch? \\ Mr. Armbruster. Here we do not rush to drugstore for chicken sandwich \& \\ Coca-Cola. Here, we take our time. We cook our pasta, we sprinkle our \\ Parmigiano, we drink our wine, we make our love... \\ What do you do in the evening? \\ In the evening, we go home to our wives.
}

Through the words of Carlucci, Wilder criticises US lifestyle in "...we do not rush to drugstore for chicken sandwich \& Coca-Cola," and as in his "French" movies, highlights the importance of sex, and normalizes adultery. When the coroner is late at the morgue, it is because "he eats very well. He knows all the widows." Moreover, Wilder delights in criticising American's poor taste in, for example, coffee. Armbruster is constantly complaining about Italian coffee "When are these people going to learn how to make a decent cup of coffee?" And when Carlucci suggests Armbruster calms down with a mud bath, the following exchange follows:

\section{Example 26}

\section{Character Dialogue \\ Armbruster: $\quad$ No thanks, I had one on the train. \\ Carlo Carlucci: On the train? \\ Armbruster: $\quad$ I drank it. They call it espresso.}

Of course, we laugh at Armbruster's lack of taste in his inability to appreciate what is generally considered to be excellent coffee. In fact, from the moment he lands in Italy, Armbruster acts arrogantly. At passport control through no fault of the police officer, Armbruster is held up and so immediately gets angry and shouts, "I know you foreigners, I know how you love to push Americans around..." Similarly, J.J. Blodgett, (Edward Andrews) who arrives in Ischia from the US State Department to help Armbruster and who speaks no Italian magnanimously says that he doesn't "... object to foreigners speaking a foreign language. I just wish they'd all speak the same foreign language" which is presumably English. And just as Schleemer in One, Two, Three was nostalgic for the past, here too we find a character pining for the "good old days": 


\title{
Example 27
}

\author{
Character \\ J.J. Blodgett: What the hell is going on in this country? This wouldn't have happened in the \\ old days! \\ Helicopter pilot: You remember Mussolini?
}

Here too, through Blodgett, Wilder goes to town on US Republican ideals. As Blodgett's helicopter is about to land on Ischia, he is worried that:

\section{Example 28}

\section{Character J.J. Blodgett: Helicopter pilot: J.J. Blodgett:}

\author{
Dialogue \\ Maybe it's one of those Greek islands? \\ No sir, Greece is way to the left. \\ Not as long as I am with the State Department!
}

Last, but certainly not least, when a group of local farmers kidnap the two corpses and Armbruster realizes that the law is unable to help him he complains about Italian justice to which Carlucci fittingly responds

\section{Example 29}

\begin{tabular}{|c|c|}
\hline Character & Dialogue \\
\hline $\begin{array}{l}\text { Armbruster: } \\
\text { Carlo Carlucci: }\end{array}$ & Is that what you call Italian justice? \\
\hline
\end{tabular}

\section{Conclusion}

The analysis of four films chosen from the rich cinematic production of Billy Wilder has led us to discuss the ways in which the Austrian-born American director has depicted cultural diversity on screen. Being an outsider himself, Wilder had the advantage of "surfing" between cultures. This privileged position allowed him to look at the others with a "certain gaze," frequently resorting to humour as a lens through which he and his audience could see the world and its differences. At times, he uses more benevolent mockery, at others, more caustic derision. Our analysis focuses on a number of examples taken from a small but significant sample of Wilder's films. The four films have offered an overview of the multi-modal portrayals of many diverse "foreigners," namely Germans, Russians, French, and Italians. From the bad Germans to the nationalistic French, a common feature seems to emerge when dealing with intercultural encounters, each party has a certain perception of the other. This perception is often based and built on a stereotypical representation of cultural diversity. The Germans are portrayed as having a yearning for their militaristic past (Examples 4 and 5), but in contrast so have the Americans (Example 28); the Russians and Americans continually battle in one-upmanship with neither truly coming out top (Example 10). Wilder portrays the French as a nation of people who place sexual activity before everything else (Example 16) while the Americans are mostly concerned with financial gain. As for Italians, the examples from Avanti! portray them in a perpetual state of confusion and chaos, yet with time to enjoy the good things in life such as food, relaxation and love, unlike fast-living Americans.

Despite the happy-go-lucky atmosphere that Wilder's films may have to some, this is only a superficial characteristic. The combination of humour with what appears to be a wellgrounded reflection of the reality around him provides the director's cinematic production with an undeniable appeal that still persists today. Suffice it to think about Wilder's opinions 
of the USA - especially its fear of left-wing politics, love of money, and rigid sexual morals to realize how contemporary and relevant this representation turns out to be.

On a more analytical level, the four films have shown a common feature of multilingual humour. When cultural mockery is at work, the humour derived is based on a common background, a stereotypical perception and representation of the other. As long as the film's audience share and/or is willing to share such a standpoint, humour may function effectively. On the contrary, when viewers do not share such a cultural scenario, humour risks falling flat. In a nutshell, multilingual humour at the movies proves to be a culture-specific feature. In order to study this further, the way ahead can only be an interdisciplinary approach in which humour scholars collaborate with scholars in film studies, cultural studies and linguistics.

\section{References}

Baldo, M. (2009). 'Subtitling multilingual films. The case of Lives of the Saints, an ItalianCanadian TV screenplay', in Federici, F. M. (ed.), Translating Regionalised Voices in Audiovisuals, Roma: Aracne, pp.117-135.

Chiaro, D. (2007). 'Lost, found or retrieved in translation? Cross-language humour in multilingual films', in Scelfo M. G. \& Petroni S. (eds.), Lingua, cultura e ideologia nella traduzione di testi multimediali (Cinema, televisione, web), Roma: Aracne, pp. 123-137.

Chiaro, D. (2010). 'Found in translation: cross-talk as a form of humour', in Valero-Garcés C. (ed.), Dimensions of Humor: Explorations in Linguistics, Literature, Cultural Studies and Translation, València: Universitat de València, pp. 33-54.

Chiaro, D. (2015). 'Mimesis, reality and fictitious intermediation', in Antonini R. \& Bucaria C. (eds.), Non-professional Interpreting and Translation in the Media, Bern - Berlin Bruxelles - Frankfurt am Main - New York - Oxford - Wien: Peter Lang, pp. 23-42.

Chiaro, D. (2017). 'Humor and translation', in Attardo S. (ed.), The Routledge Handbook of Language and Humor, New York: Routledge.

Chiaro, D. (2018). 'Cross-languaging romance on screen', in Abend-David D. (ed.), Representing Translation, New York: Benjamins.

Davies, C. (1990). Ethnic Humor Around the World: A Comparative Analysis. Indiana University Press: Bloomington Indiana.

Davies, C. (1998). Jokes and their Relation to Society. Berlin: Mouton de Gruyter.

Davies, C. (2002). The Mirth of Nations. New Brunswick: Transaction.

De Bonis, G. (2014a). Commedia in scompiglio: One, Two, Three. Il multilinguismo come veicolo di umorismo', in De Rosa G. L., Bianchi F., De Laurentiis A. \& Perego E. (eds.), Translating Humour in Audiovisual Texts, Bern - Berlin - Bruxelles - Frankfurt am Main - New York - Oxford - Wien: Peter Lang, pp. 189-214.

De Bonis, G. (2014b). 'The semiotic implications of multilingualism in the construction of suspense in Alfred Hitchcock's films', in Cadera, S. M. \& Pavic Pintaric, A. (eds.), The Voices of Suspense and Their Translation in Thrillers, Amsterdam - New York: Rodopi, pp. 141-158.

De Bonis, G. (2015a). 'Translating multilingualism in film: A case study on Le concert'. New Voices in Translation Studies, 12 (2015). IPCITI 2013 Proceedings. Guest-edited by P. Castillo, P. Karanasiou, M. Shamy \& L. Williamson, pp. 50-71.

De Bonis, G. (2015b). Tradurre il multilinguismo al cinema: Lingue, identità culturali e loro rappresentazione sullo schermo. Bologna: University of Bologna. Unpublished $\mathrm{PhD}$ Thesis.

De Bonis, G. (2015c). 'Mediating intercultural encounters on screen. The representation of non-professional interpreting in film', in Antonini R. \& Bucaria C. (eds.), Non- 
professional Interpreting and Translation in the Media, Bern - Berlin - Bruxelles Frankfurt am Main - New York - Oxford - Wien: Peter Lang, pp. 43-64.

Delabastita, D. (2002). 'A great feast of languages. Shakespeare's multilingual comedy in "King Henry V" and the Translator'. The Translator, 8(2), pp. 303-340.

Delabastita, D. (2005). 'Cross-language comedy in Shakespeare'. HUMOR - International Journal of Humor Research. Special Issue Humor and Translation, 18(2), pp. 161-184.

Delabastita, D. (2010). 'Language, comedy and translation in the BBC sitcom 'Allo 'Allo!', in Chiaro D. (ed.), Translation, Humour and the Media, London - New York: Continuum, pp. 193-221.

O’Sullivan, C. (2011). Translating Popular Film. Basingstoke: Palgrave Macmillan.

Sternberg, M. (1981). 'Polylingualism as reality and translation as mimesis'. Poetics Today, 2(4), pp. 221-239.

Wahl, C. (2005). 'Discovering a genre: the polyglot film'. Cinemascope 1: Translating the cinematic experience across cultures: $1-8$.

Wahl, C. (2008). 'Du Deutscher, Toi Français, You English: Beautiful! - The polyglot film as a genre', in Christensen, M. \& Erdŏgan, N. (eds.) Shifting Landscapes. Film and Media in European Context, Newcastle: Cambridge Scholars Publishing, pp. 334-350.

\section{Films \& TV series cited}

Avanti! (USA, Italy, 1972)

Fawlty Towers (UK, BBC2, 1975-1979)

Irma La Douce (USA, 1963)

Love in the Afternoon (USA, 1957)

One, Two, Three (USA, 1961)

Sabrina (USA, 1954) 